\title{
Child-rearing and children's empathy
}

Gisela Trommsdorff 
Summary.-The prediction of higher empathy for children whose mothers were generally more empathetic and in interaction with their children was confirmed for 15 boys and 15 girls, 5 to 6 years old, and their mothers. Teachers' ratings of childre correlated significantly with several maternal variables: with empathy, frequency of mothers' articulation of prosocial goals and understanding of the child.

The study of empathy and its development gives insight into the development of prosocial motivation. Empathy is regarded here as an otheroriented emotional reaction involving concern for the other's well-being. Such empathic concern (often called "sympathy") (Eisenberg, 1986) can induce prosocial behavior and can be conceptually linked to altruistic motivation. Socialization in the family, and more specifically maternal behavior, has been considered to be an important basis for the development of empathy. Maternal empathy (Strayer, 1987), maternal perspective-taking ability (Fabes, Eisenberg, \& Miller, 1990), warm parenting (Barnett, 1987), and reasoning (Zahn-Waxler, Radke-Yarrow, \& Kind, 1979) are positively related to children's emotional responsiveness. However, most of the above-mentioned studies assessed empathy by using self-report measures and by using mostly situation-specific measures of children's empathic responses.

In the present study, empathy is assessed as a prosocial disposition on the basis of expert ratings (by trained kindergarten teachers). In line with the literature, we predicted higher empathy for children whose mothers were more empathic in general and in interaction with their children (Zahn-Waxler, et al., 1979).

\section{METHOD}

Subjects

In a small German city (Aachen), 30 kindergarten children (15 boys and 15 girls), between 5.1 and 6.4 yr. of age, and their mothers participated in this study.

This study is part of a broader research project on the socialization of empathy which was financially supported by the Technische Universität Aachen. The present study is based on a selection of raw data collected by Elke Auer as part of her graduation thesis (Diplom). Some of these data have been reanalysed with financial support of the Universität Konstanz for the
purpose of the present study. Special thanks go to the mothers, kindergarten teachers and the purpose of the present study. Special thanks go to the mothers, kindergarten teachers and the
children who volunteered in this study. Requests for reprints should be addressed to Gisela
Trommsdorff, Lehrstuhl für Entwicklungspsychologie, Universität Konstanz, PF 5560, 7750 Konstanz, Germany. 
Procedure

Children.-Children's empathy was measured with the help of ratings of kindergarten teachers, who had known the children for more than one year. The teachers were instructed in eight training sessions (each lasting between 2 and $4 \frac{1}{2}$ hours). The teachers first learned to operationalize the concept "empathy." They then were asked to describe empathy-related behavior of the children observed while interacting in different situations in the kindergarten. Finally, they were asked to rate the children's empathy on a 5-point scale. Sufficient intra- and interrater reliability was achieved at this time.

Mothers. - First, each mother was asked to complete the German translation of the empathy scale of Mehrabian and Epstein (1972). This scale consists of 23 items (1: do not at all agree ... 5: agree very much). Second, mothers were interviewed using a semiprojective test (Sozialisations-Situationen-Verfahren) by Kornadt (1989). The instrument consists of 12 situations, seven by Kornadt (1989) and five by Auer (1987), each of which illustrates a conflict between mother and child (e.g., mother and child are playing on the playground; mother wants to go home and child does not want to follow). Each mother then answered several questions about her reaction, e.g., what she would do in this situation; why; why she believes the child behaves as it does. The mothers' answers were coded according to a theoretically derived coding system to measure child-rearing goals and practices.

\section{RESULTS AND DisCUSSION}

Pearson correlations were computed between the children's empathy and all aspects of the maternal variables. First, correlations between children's and mothers' empathy were significant $(r=.61, p<.001)$. Second, significant correlations occurred between some variables of mothers' child-rearing and children's empathy: the frequency of mothers' articulation of prosocial goals $(r=.56)$ and their understanding for the child $(r=.54)$; see Table 1 .

Comparisons between children high vs low in empathy (median split; $M=3.0$ ) showed that mothers of more highly empathic children were significantly higher in empathy, showed more understanding for their children, and pursued more prosocial goals $(p<.05, t$ tests for independent samples). Mothers of highly empathic children tended to fewer direct demands to make their child give in $(t=-2.12, p<.08)$; see Table 2 .

These results confirm the assumption that mothers' and children's empathy are closely related. Furthermore, several child-rearing goals and practices were significantly related to the children's disposition to be empathic. These findings are consistent with the very few. data on maternal correlates of children's empathy (Barnett, 1987; Fabes, Eisenberg, \& Miller, 1990). Our data suggest that empathy-related beliefs and behavior of mothers are important variables for the development of prosocial orientations of children.
TABLE 1

Pearson Correlatton Matrix For Children's Empathy and Mothers' Behavior

\begin{tabular}{|c|c|c|c|c|c|c|c|c|c|c|}
\hline \multirow{3}{*}{$\begin{array}{l}\text { Measure } \\
\text { 1. Children's empathy } \\
\text { 2. Mothers' empathy }\end{array}$} & & 1 & 2 & 3 & 4 & 5 & 6 & 7 & 8 & 9 \\
\hline & & & & & & & & & & \\
\hline & $\begin{array}{l}r \\
n\end{array}$ & $\begin{array}{l}.61 \ddagger \\
33\end{array}$ & & & & & & & & \\
\hline 3. Understanding child & $\begin{array}{l}r \\
n\end{array}$ & $\begin{array}{l}.54 \ddagger \\
33\end{array}$ & $\begin{array}{l}.32 \\
33\end{array}$ & & & & & & & \\
\hline 4. Intention & $\begin{array}{l}r \\
n\end{array}$ & $\begin{array}{r}-.13 \\
16\end{array}$ & $\begin{array}{r}.13 \\
16\end{array}$ & $\begin{array}{r}-.19 \\
16\end{array}$ & & & & & & \\
\hline 5. Prosocial goals & $\begin{array}{l}r \\
n\end{array}$ & $\begin{array}{l}.56 \dagger \\
27\end{array}$ & $\begin{array}{r}.19 \\
27\end{array}$ & $\begin{array}{l}.32 \\
27\end{array}$ & $\begin{array}{l}.02 \\
15\end{array}$ & & & & & \\
\hline 6. Explaining & $\begin{array}{l}r \\
n\end{array}$ & $\begin{array}{r}.10 \\
28\end{array}$ & $\begin{array}{r}.24 \\
28\end{array}$ & $\begin{array}{l}.22 \\
28\end{array}$ & $\begin{array}{r}-.26 \\
15\end{array}$ & $\begin{array}{r}-.08 \\
23\end{array}$ & & & & \\
\hline 7. Demands & $\begin{array}{l}r \\
n\end{array}$ & $\begin{array}{r}-.44 \\
12\end{array}$ & $\begin{array}{c}-.56^{*} \\
12\end{array}$ & $\begin{array}{c}-.75 \dagger \\
12\end{array}$ & $\begin{array}{r}.00 \\
6\end{array}$ & $\begin{array}{r}-.53 \\
9\end{array}$ & $\begin{array}{r}-.55 \\
12\end{array}$ & & & \\
\hline $\begin{array}{l}\text { 8. Focus on other } \\
\text { person's needs }\end{array}$ & $\begin{array}{l}r \\
n\end{array}$ & $\begin{array}{l}.17 \\
26\end{array}$ & $\begin{array}{c}.45^{*} \\
26\end{array}$ & $\begin{array}{r}-.10 \\
26\end{array}$ & $\begin{array}{r}-.27 \\
14\end{array}$ & $\begin{array}{r}-.13 \\
24\end{array}$ & $\begin{array}{l}.43^{*} \\
21\end{array}$ & $\begin{array}{r}-.38 \\
8\end{array}$ & & \\
\hline $\begin{array}{l}\text { 9. Focus on } \\
\text { mothers' needs }\end{array}$ & $\begin{array}{l}r \\
n\end{array}$ & $\begin{array}{r}.34 \\
19\end{array}$ & $\begin{array}{r}.15 \\
19\end{array}$ & $\begin{array}{l}.68 \ddagger \\
19\end{array}$ & $\begin{array}{r}.27 \\
13\end{array}$ & $\begin{array}{r}.13 \\
18\end{array}$ & $\begin{array}{r}.04 \\
19\end{array}$ & $\begin{array}{r}.00 \\
5\end{array}$ & $\begin{array}{r}-.30 \\
17\end{array}$ & \\
\hline
\end{tabular}

Note. $-2-9$ : mothers' behavior. ${ }^{*} p<.05 . \dagger p<.01 . \ddagger p<.001$.

The role of mothers in the development of their children's empathy may consist in presenting themselves as models for identification (Radke-Yarrow, Zahn-Waxler, \& Chapman, 1983) and setting prosocial goals. However,

TABLE 2

Mothers' ChILd ReARING ANd ChIIDREN's Empathy

\begin{tabular}{|c|c|c|c|c|c|c|c|}
\hline \multirow[t]{3}{*}{ Variable } & \multicolumn{6}{|c|}{ Children's Empathy } & \multirow[t]{3}{*}{$t$} \\
\hline & \multicolumn{2}{|c|}{ Low } & \multicolumn{2}{|c|}{ High } & \multicolumn{2}{|c|}{ Total } & \\
\hline & $M$ & $S D$ & $M$ & $S D$ & $M$ & $S D$ & \\
\hline Mothers' empathy & 18.63 & 8.23 & 27.76 & 5.29 & 23.33 & 8.20 & $3.77^{*}$ \\
\hline Understanding child & 1.94 & 1.65 & 3.24 & 1.25 & 2.61 & 1.58 & $2.53 *$ \\
\hline Intention & 1.60 & 0.55 & 1.55 & 0.52 & 1.56 & 0.51 & $<1.00$ \\
\hline Prosocial goals & 1.90 & 0.74 & 2.71 & 0.92 & 2.41 & 0.93 & $2.50 *$ \\
\hline Explaining & 2.58 & 1.31 & 2.75 & 1.18 & 2.68 & 1.22 & $<1.00$ \\
\hline Demands & 1.43 & 0.53 & 1.00 & 0.00 & 1.25 & 0.45 & -2.12 \\
\hline Focus on other person's needs & 1.40 & 0.52 & 1.63 & 0.62 & 1.54 & 0.58 & 1.00 \\
\hline Focus on mothers' needs & 2.25 & 0.50 & 2.27 & 0.80 & 2.26 & 0.73 & $<1.00$ \\
\hline
\end{tabular}

${ }^{*} p<.05$.

identification with a prosocial model and internalization of prosocial goals require a close emotional relationship between model and child. Such a relationship may develop more easily when mothers demonstrate understanding for their children's needs. On the other hand, mothers requiring compliance 
from their children seem to stimulate reactance. Interestingly, these mothers are low in empathy. Their behavior may induce the development of self-concerned rather than other-concerned reactions in the child.

The described pattern of maternal correlates of children's empathy raises the question whether empathy develops as an aspect of relating the self to the environment (Trommsdorff \& John, 1991). Especially the mother's effort to experience vicariously the child's needs-an essential aspect of secondary (in contrast to primary) control orientation (cf. Rothbaum, Weisz, \& Snyder, 1982) seems to be an important factor in the development of empathy. Therefore, we are presently studying the effects of growing up with a belief system of primary vs secondary control orientation in different cultures.

\section{REFERENCES} AUER, E. (1987) Empathiebezogene Erziehung der Mutter und Empathiefähigkeit des Kindes.
Unpublished graduation thesis, Technische Universität, Aachen.

BARNETT, M. A. (1987) Empathy and related responses in children. In N. Eisenberg \& J. Pp. 146-162.

EIsenBerg, N. (1986) Altruistic emotion, cognition, and behavior. Hillsdale, NJ: Erlbaum.

Fabes, R. A., EIsenberG, N., \& MirLeR, P. (1990) Maternal correlates of children's vicarious emotional responsiveness. Developmental Psychology, 26, 639-648.

KorNADT, H-J. (1989) Frühe Mutter-Kind-Beziehungen im Kulturvergleich. In G. Trommsdorf (Ed.), Sozialisation im Kulturvergleich. Stuttgart: Enke. Pp. 65-96.

Mehrabian, A., \& Epstein, N. A. (1972) A measure of emotional empathy. Journal of Person ality, $40,525-543$.

RADKE-YARROW, M., ZAHN-WAXIER, C., \& CHAPMAN, M. (1983) Children's prosocial dispositions and behavior. In E. M. Hetherington, W. Kessen, M. Haith, \& P. H. Mussen (Eds.), Handbook of child psychology: socialization, personality, and social development.
Vol. 4. (4th ed.) New York: Wiley. Pp. 468-546. self: a two Psychology, 42, 5-37.

STRAYER, J. (1987) Affective and cognitive perspectives on empathy. In N. Eisenberg (Ed.), DORFF, G., \& JOHN, H. (1991) Decoding affective communication in intimate relations. European Journal of Social Psychology, in press.

ZAHN-WAXIER, C., RADKE-YARROW, M., \& KING, R. A. (1979) Child-rearing and children's prosocial initiations toward victims of distress. Child Development, 50, 319-330. 